The riot is positioned by some contemporary
Left theorists and activists as the harbinger
of a future emancipatory politics. This view has
emerged in a period of political transition in
which traditional modes of Left organisation
are routinely dismissed as ineffective. This paper
examines the history of the riot in Aotearoa
New Zealand, seeking to understand what role,
if any, the riot might play in this country's future. 


\section{Riots, Strikes, and Radical Politics in Aotearoa New Zealand}

\section{DYLAN TAYLOR}

The current moment is widely regarded as transitional, an interregnum. ${ }^{1}$ There is a general consensus, on the Left at least, as to the nature of the difficulties we face-of the environment, democracy, economy, race relations. But how to move toward a more just and equitable society is not yet clear. To be in a transitional period involves engaging in reactive, rear-guard actions, defending previously fought gains. It also involves an extended dialogue between us, a search for ways to move forward, of asking what our shared values and goals might be, how we might (re)organise collectively, and how we might productively work with our differences.

A transitional period also involves an intensification of the search for actually-existing examples of alternative ways of being, or sites of resistance and unrest, in the hope these might harbour wider emancipatory possibilities.

The turn of much contemporary radical Left thought towards the riot is an example of this latter tendency. The Greek communisation grouping Blaumachen argue that 'we are entering into an era of riot, which will be transitional and

1 I am deeply indebted to the close and insightful engagement of Toby Boraman and Cybèle Locke with an earlier draft of this article. I am also very fortunate to have had input from Amanda Thomas, Sue Bradford, Mark Derby, Graeme Whimp, Jennifer de Saxe, and Eli Elinoff. Jack Foster has provided excellent (and patient) editorial assistance. All mistakes and omissions are mine alone. 
extremely violent ${ }^{2}$ Badiou suggests the mass-popular riots of 2011 indicate that we are witnessing a rebirth of the possibility of socialism-communism. In 2011 regimes were overthrown in Tunisia and Egypt by popular actions that were not directed by established organisations. Riots were at the epicentre of these movements. More recently, the populist gilet jaunes (yellow vest) movement against austerity in France, which began in October 2018 and continues into 2019, has been punctuated by a series of riots and attendant police violence. 'The riot', argues Badiou, 'is the guardian of the history of emancipation' in a transitional period; it signals a 'new figure of organisation and hence of politics.' 'When it comes to liberty, equality and emancipation', he asserts, 'we owe everything to popular riots'. Riots stir people up. They show that the present is unacceptable. For Badiou, they have the potential to open a new political sequence, to alter our sense of what is possible. ${ }^{4}$

The common view of riots is of spontaneous, mindless eruptions of violence against private property and persons. A different approach to the riot is taken here, one that contextualises it within long-term economic dynamics and their intersection with political contestation. Here I am indebted to Joshua Clover's Riot. Strike. Riot, which is a comprehensive attempt to theorise the riot in its contemporary context within Western societies. ${ }^{5}$

In the first section I unpack Clover's theorisation and periodisation of the riot. Clover suggests that the riot was the most commonly deployed form of collective action in Western Europe in the pre-industrial period, only to be superseded by the strike in the $19^{\text {th }}$ century. The riot has made a comeback from the late 1960s, he contends, because of the declining power of organised labour-a decline tied to changing racial and generational dynamics.

Has recent history witnessed a resurgence of the riot in Aotearoa New Zealand? I consider this question in the remainder of the article. In the

2 Blaumachen, 'The Transitional Phase of the Crisis: The Era of Riots,' blaumachen. $g r$, http://www.blaumachen.gr/2011/07/the-transitional-phase-of-the-crisis-the-era-ofriots [emphasis in original].

3 Alain Badiou, The Rebirth of History (London: Verso, 2012), 41-2.

4 Badiou, The Rebirth of History, 107.

5 Joshua Clover, Riot. Strike. Riot: The New Era of Uprisings (London: Verso, 2016). 
second section I examine the little-studied history of riots in this county. In the third section I set this history against that of strikes and organised labour. Finally, in the fourth section I explore how this country's racial dynamics might contribute to forms of contention other than those of the riot. I argue that the history of riots and strikes in this country differs, for the most part, from Clover's periodisation. The riot is less prevalent in Aotearoa New Zealand, in part because of different racial dynamics and particular traditions of organisation and resistance.

While not always explicitly drawn together, two main threads run through the discussion of riots here: race and class. Gender is a salient third term, but a sustained treatment of this falls outside the scope of the article. ${ }^{6}$ It will be seen that the state often provokes riots and determines what is counted as a riot or who is branded a rioter. Further, it will be seen that while the riot is often spectacular-plumes of black smoke rising from burnt-out shop-fronts, the hooded rioter fleeing police-it is also something that manifests in a lower key, in what Clover suggests is a 'modality of life' for populations excluded from economic opportunities: a low-level and constant 'criminality' and 'anti-social' logic present in certain underprivileged areas. My intention here is not to argue for a spontaneist-insurrectionist approach to politics; rather, I aim to highlight the importance of taking the riot's dynamics into account when considering political organisation.

\section{Conceptualising riots}

The riot deserves a theory, asserts Clover, and 'a theory of riot is a theory of crisis'. This entails an historical view of the ongoing and systemic crises

6 But see: Fran Shor, 'Bringing the Storm: Syndicalist Counterpublics and the Industrial Workers of the World in New Zealand, 1908-14,' in On the Left: Essays in Socialism in New Zealand, ed. Pat Moloney and Kerry Taylor (Dunedin: Otago University Press, 2002); Cybèle Locke, 'Rebel Girls and Pram-Pushing Scab-Hunters: Waihi “Scarlet Runners,” 1912,' Labour History 107 (2014): 35-51.

7 Clover, Riot. Strike. Riot, 1. 
of capital. In Clover's periodisation, the first phase of the riot precedes the Industrial Revolution. He has us begin in 1347, at the English ports of the Hanseatic League, where we witness riots against the exportation of food in a time of famine. In the years that follow, riots accompany the growth of national and international markets, the commoditisation of agriculture, and enclosure of the commons. They are circulation struggles, conducted at the port or market, seeking to control the movement and price of goods. At stake is the social reproduction of individuals, households, and communities. Riots are concerned with issues of consumption.

The strike, in contrast, arises as a response to issues of production. The transition from riot to strike takes place between the late- $18^{\text {th }}$ and $\mathrm{mid}-19^{\text {th }}$ centuries, in step with the entrenchment of industrial capitalism. Again, England is the crucible. The strike emerges from the riot. The machinewreckers are indicative of this shift, deploying the eruptive tactics of the riot against the means of industrial production. ${ }^{8}$ The strike came to distinguish itself as a tactic of collective action on the basis of being 'ordered' - disciplined rather than chaotic, planned rather than spontaneous. ' The factory floor is the site of the strike. Social reproduction is still the focus of action, but now it is the price of labour rather than the cost of goods that is contested. The strike is conducted by workers acting self-consciously as workers.

The shift from strike back to riot corresponds to the changing dynamics of capital: the flexibilisation of labour, the 'offshoring' of production from core to peripheral states, advancements in global logistics, technological developments in production and communication. ${ }^{10}$ Against this backdrop, argues Clover, labour has been reduced to 'defensive negotiations, compelled

8 For a classic essay on this transition see: Eric Hobsbawm, 'The Machine-Breakers,' in Uncommon People: Resistance, Rebellion and Jazz (London: Weidenfeld \& Nicolson, 1998), 5-17.

9 This is not to say that the riot disappears from the mid- $19^{\text {th }}$ century, but rather that it ceases to be the leading tactic for contentious politics; conversely, in the era of contemporary riots beginning in the late 1960 s, the strike persists, but the riot is now the dominant tactic.

10 Clover uses the term 'riot prime' to designate the period of riot that opens from the late 1960 s through to the present day; I will refer to this as the 'contemporary riot'. 
to preserve the firms able to supply wages, affirming the domination of capital in return for its own preservation'. ${ }^{11}$ He goes so far as to assert that, in seeking to maintain the labour relation, the working class is caught in an 'affirmation trap', 'locked into the position of affirming its own exploitation under the guise of survival'. ${ }^{12}$ The communisation groups Rocamadur and Blaumachen share this perspective. They view the riot as a political site that offers 'no ground for a revolutionary affirmation of class belonging, no workers' identity or proletarian community. ${ }^{13}$ Rather, riots reflect the fact that class belonging is 'an element that is foreign to everyone's life: the hostile embodiment of the dominating power of capital'. ${ }^{14}$ As with class, so too those who would represent its interests:

As the representative of a political party, of a union or any other established institution, one cannot 'organise' and 'coordinate' the burning of the police offices or the sabotage of infrastructures, simply because one incarnates the very society that is being attacked through these practices, and that one's existence as such a representative presupposes that of urban administration, of police control, of the cleavage between social citizens and 'outsiders'. ${ }^{15}$

The thinking of the riot, then, is an attempt to grapple with the changing dynamics of capital and the accompanying struggles.

Although the strike persisted as the most significant tactic of collective action well into the 1970s, the riot has become increasingly prevalent since the 1960s. The 1967 uprising in Detroit (coming shortly after urban rebellion in Newark) is a prominent example of this tendency. As noted by Bloom and Martin Jr:

11 Clover, Riot. Strike. Riot, 30.

12 Clover, Riot. Strike. Riot, 147.

13 Rocamadur/Blaumachen, 'The Feral Underclass Hits the Streets: On the English Riots and Other Ordeals,' SIC 2 (2014): 123.

14 Leon de Mattis, 'Comunist Measures: Thinking a Communist Horizon,' SIC 2 (2014): 60 .

15 Zaschia Bouzarri, 'Arson with Demands — on the Swedish Riots,' SIC 3 (2015): 22-23. 
Rebels not only looted but also turned to more serious insurrectionary tactics, such as arson and sniping. Unlike looting . . . these activities subjected rebels to significant risk while offering no instant material benefit, thus suggesting a challenge to the social order. ${ }^{16}$

The uprising raged over five days; 552 buildings were destroyed or damaged by fire; 7,231 people were arrested and 43 people killed (including government officials). ${ }^{17}$ In step with Bloom and Martin Jr, Clover holds that this uprising (and others at the time) were not eruptions of spontaneous, mindless violence, but something that is 'continuous with a larger political development', that of the Black Power movement. ${ }^{18}$ The uprising's location in Detroit makes it a signal event, as this is an early example of a city undergoing deindustrialisation. The city's population was in steep decline by this point; economic growth had stagnated around 1960 , and the union policy of 'last hired, first fired' disproportionately impacted African-American workers. ${ }^{19}$ The Detroit riot of 1967 and the political and economic context in which it erupted signal the racialised dimension of the contemporary riot.

The notion of 'relative surplus population' helps contextualise this interplay between racism, unemployment and economic precarity, and the impulse to riot. Marx argued that capitalism produces a 'relative surplus population'. As labour becomes more productive, and the means of production more efficient, there is a corresponding decline in the demand for labour. A portion of the population becomes 'surplus' relative to the needs of capital. They are pushed to the edge of, or even outside, the workforce. Their existence has a disciplinary effect on labour, as capitalists are able to depress wages and intensify the workload of those who remain employed. As Marx argues, 'The relative surplus population is . . the background against which the law of the demand and supply of labour does

16 Joshua Bloom and Waldo Martin Jr, Black against Empire: The History and Politics of the Black Panther Party (Berkely CA: Univesity of California Press, 2013), 87.

17 Bloom and Martin Jr, Black against Empire, 87.

18 Clover, Riot. Strike. Riot, 120.

19 Clover, Riot. Strike. Riot, 161. 
its work'. ${ }^{20}$ While the surplus population is not immediately required by capital in the workforce, it is of great importance to capitalists as it allows them to increase the surplus value extracted from the work of others. The surplus population is not homogenous. It comprises those whose skills are obsolete or whose bodies have been degraded through hard graft as well as the homeless, precarious part-time workers, migrant workers, orphans, and the demoralised, among others. ${ }^{21}$

Clover highlights the growth of the surplus population since the late 1960s as a key element in the ascendency of the riot as a collective tactic: 'The riot is . . . a reckoning with idled capacities'; there is a 'stagnant surplus population' that is 'chronically outside the formal wage' and 'earning less than subsistence amounts'. ${ }^{22}$ Others also highlight this tendency and its entwinement with the riot. Tyler suggests that neoliberalism produces large numbers of "“failed people" marginalised by, excluded, or disqualified from, the social body'. ${ }^{23} \mathrm{Or}$, in Žižek's formulation, the riot is, 'at its most radical, a conflict between non-society and society, between those who have nothing to lose and those who have everything to lose'. ${ }^{24}$ The riot provides a means of thinking the place of 'surplus populations' in relation to the state and capital, and of what the resistance of such populations might entail.

Within the category of surplus population, as applied to the contemporary situation, Clover suggests there is a 'unity of the excluded and indebted, encompassing class and race and their intersection. ${ }^{25}$ The contemporary riot, he argues, has two sources: 'One . . . arises from youth discovering that the routes that once promised a minimally formal integration into the economy are now foreclosed. The other arises from

20 Karl Marx, Capital, volume I, trans. Ben Fowkes (London: Penguin, 1990), 792.

21 Marx, Capital, vol. I, 794-797.

22 Clover, Riot. Strike. Riot, 155, 156.

23 Imogen Tyler, Revolting Subjects: Social Abjection and Resistance in Neoliberal Britain (London: Zed, 2013), 198.

24 Slavoj Žižek, The Year of Dreaming Dangerously (London: Verso, 2012), 60 [emphasis in original].

25 Clover, Riot. Strike. Riot, 157 [emphasis in original]. 
racialised surplus populations and the violent state management thereof' ${ }^{26}$ In recent years, examples of the former include: student struggles in London in 2010, which included occupations and the sacking of a Tory headquarters; a series of university occupations in 2009-2010 across California, which met with militarised repression; Occupy Oakland in 2011; and the Chilean student struggles of 2011-2013. Examples of the latter in recent years include: Sydney in 2004, in response to the death of Thomas Hickey during a police pursuit; Paris in 2005, following the deaths of Zyed Benna and Bouna Traoré while fleeing police; Oakland in 2009, following the police murder of Oscar Grant; the Tottenham riots of 2011, after the police killing of Mark Duggan; and the 2014 Ferguson riots, after the shooting of Michael Brown. These riots are indicative of a period where the 'Keynesian compromise' between capital and the state that characterised the three decades following the Second World War has collapsed-a compromise in which the state stabilised the economy in times of crisis, provided comprehensive welfare, and supported full employment, while capital, for its part, provided stable employment conditions and relatively high wages. Following the dissolution of this compromise the repression of racialised populations has intensified. Today, Clover argues, we have 'police occupation of excluded communities. Police and riot ... presuppose each other. ${ }^{27}$

While the above examples are clearly riotous, when is a riot no longer a riot? Clover argues for an expansive view, one that encompasses the notion of riot as 'social modality'. Here his thinking is informed by the perceived 'continuity between Black Power and riot' in the context of the United States' turbulent 1960s: 'Negroes are blackness is riot. At least in 1968. Insofar as riot is a category recognised by state, law, and market, blacks coming down the street will always be a riot, or the moment before, or the moment after'. ${ }^{28}$ 'Riot as social modality' refers to a situation in which an

26 Clover, Riot. Strike. Riot, 180.

27 Clover, Riot. Strike. Riot, 180.

28 Clover, Riot. Strike. Riot, 120, 122. 
aggrieved group's desire for collective action must pass through the riot to find expression. It is the reserve of

a collective population rendered surplus and forced to confront the problem of reproduction in the marketplace rather than in the formal wage - in this situation, any gathering on the corner, in the street, in the square can be understood as a riot. ... [It] is hard to tell when and where the riot starts and ends. ${ }^{29}$

The external viewer, for whom 'blackness is riot', projects 'riot' onto surplus populations, coding their struggles for social reproduction as riotous. In conceptualising the riot in this broader sense, as a 'social modality', Clover offers a means of thinking beyond the spectacular dimension of the riot towards the mundane, day-to-day experiences of surplus populations excluded from economic and political opportunities.

Clover argues that riots tend to divide into two impulses shortly after their irruption. The first is the movement towards populism-the path of political respectability that leads to the electoral arena-with the riot transformed into a demand that can be satisfied by the current order. The second impulse is the riot as 'something beyond or before communication' characterised by immediate practicalities: 'looting, controlling space, and destroying property understood to constitute the rioters' exclusion from the world they see always before them and which they may not enter'. ${ }^{30}$

Since the era of the Civil Rights movement in the United States, the first path has most been the most frequently travelled. Today, the growing ranks of the surplus population confront a state increasingly unable to meet their demands; correspondingly, the state is ever more punitive. It is to the second, incommunicable, impulse that Clover would have us turn to appreciate the political potential of the riot-a potential that stems from its proximity to the commune. As Clover writes, 'If the square and the street have been the places of [the contemporary riot], they both open onto the commune. The commune, however, is not a place ... it is instead a social

29 Clover, Riot. Strike. Riot, 123.

30 Clover, Riot. Strike. Riot, 185. 
relation, a political form, an event'. ${ }^{31}$ The potential of the riot lies not in what it immediately is, but in what it might become: an impulse that opens onto non-capitalist forms of social reproduction. The riot is a politics of becoming.

To summarise, Clover argues that the increased frequency of the riot in contemporary Western societies needs to be thought in conjunction with the changing dynamics of capitalism since the 1970s. The riot is a struggle arising from frustrations around the capacity of individuals and communities to reproduce themselves (physically and/or subjectively) in the sphere of consumption. This takes place against the backdrop of the declining capacity (or willingness) of the state to ameliorate the privations capital visits upon large swathes of the population. The riot is chiefly the recourse of racialised 'surplus populations', but also of youth and students whose aspirations are thwarted by diminishing opportunities. The riot is often sparked by state violence, and takes its spectacular form in looting, battles with the police, and the destruction of private property. It is also, Clover suggests, a 'modality of life' for criminalised, racialised, surplus populations who do not have recourse to such forms of collective action as the strike. The riot's political potential lies in its capacity to open new forms of collective being other than those offered by capital. Within the riot lies the possibility of the commune. Is this possibility applicable to Aotearoa New Zealand today? To begin answering this question, I turn to the history of the riot in this country.

\section{The riot}

To contextualise the riot in Aotearoa New Zealand, it is useful to begin with a broad-brush account of economic development in this country. Early colonial capitalism was marked by a brutal phase of 'primitive accumulation' in the $19^{\text {th }}$ century that forcefully separated Māori from

31 Clover, Riot. Strike. Riot, 187. In Revolting Subjects, Tyler notes that those participating in the 2011 Tottenham riots frequently reported that a sense of 'unity' developed during the riots. 
their land, leaving no alternative but to engage in waged labour. ${ }^{32}$ The economy was predominately orientated toward the agricultural sector and the extraction of primary resources, but an industrial base began to form in urban centres in the late- $19^{\text {th }}$ century. As with other countries, the New Zealand economy was subject to various booms and busts, including the Great Depression of the 1930s.

After the Second World War the country experienced a 'long boom', stretching from 1945 to 1973 . This included the largest expansion of productivity in the country's history coupled with significant technological advances; it was a time of full male employment and rising standards of living. ${ }^{33}$ The long boom gave way to a 'long depression' that began with the world recession in 1974. This was marked, among other things, by economic stagnation, balance of payments deficits, declining profitability, high unemployment, and plateauing growth in real wages. ${ }^{34}$ In response to this, and in step with international trends, there has been an increased emphasis on finance, insurance, and real estate as drivers of wealth creation - all of which depend on access to cheap credit and increased levels of debt. ${ }^{35}$

Important here has been a shift from the 'Keynesian' model of state management to a neoliberal one. The former involved a compact between labour, capital, and the state, with a commitment by the state to full employment and an expansive welfare regime. The neoliberal state has abandoned any commitment to full employment in favour of managing inflation. State assets have been privatised where possible. Those remaining in public ownership (partial or otherwise) are expected to perform as

32 Evan Poata-Smith, 'The Political Economy of Inequality between Maori and Pakeha,' in The Political Economy of New Zealand, ed. Chris Rudd and Brian Roper (Auckland: Oxford University Press, 1997), 160-179.

33 Brian Roper, Prosperity for All? Economic, Social and Political Change in New Zealand since 1935 (Southbank: Thomson/Dunmore Press, 2005).

34 Brian Roper, 'The End of the Golden Weather: New Zealand's Economic Crisis,' in State and Economy in New Zealand, ed. Brian Roper and Chris Rudd (Auckland: Oxford University Press, 1993), 1-25.

35 Jane Kelsey, The FIRE Economy (Wellington: Bridget Williams Books, 2015). 
profit-making enterprises. Economic growth recovered from the 1990s as neoliberal reforms became embedded. However, the benefits of this recovery were not evenly distributed, with levels of inequality deepening dramatically from this time. ${ }^{36}$ The notion of the 'public good' has all but disappeared. The country's remaining public services are begrudgingly doled out, with recipients routinely belittled and misled as to their legal entitlements and subject to increasingly punitive measures. ${ }^{37}$ As I discuss in more detail later, this country also has populations that are 'surplus' to capital's requirements.

\section{Historical riots}

An early instance of riot in Aotearoa New Zealand occurred in Nelson in 1843, when the superintendent of public works was assaulted. The victim held that 'a secret union does exist among them [the local workmen] in the proportion of five to one, for resisting all rules which may not be agreeable to themselves'. ${ }^{38}$ Other early examples occurred in southern goldmining areas. Religious sectarianism fuelled 'the Battle of Addison's Flat' in Otago on 3 April 1868, in which 200 men-Protestant versus Catholic_-waged a 'pitched battle'. ${ }^{39}$ The racism of 200 European miners was the cause of another riot, in which a Chinese miners' camp was destroyed in Okarito in $1871 .{ }^{40}$ As underlined by these latter two examples, riots are not always restricted to issues immediately concerned with social reproduction, nor will they automatically dovetail with left-wing concerns. However, the following discussion primarily examines riots with anti-capitalist or emancipatory

36 Max Rashbrooke, ed. Inequality: A New Zealand Crisis (Wellington: Bridget Williams Books, 2013).

37 Kelsey, The FIRE Economy.

38 Cited in Bert Roth and Janny Hammond, Toil and Trouble: The Struggle for a Better Life in New Zealand (Auckland: Methuen, 1981), 14.

39 Kevin Baker, Mutiny, Terrorism, Riots and Murder: A History of Sedition in Australia and New Zealand (Kenthurst NSW: Rosenberg, 2006), 62-63.

40 Baker, Mutiny, Terrorism, Riots and Murder. 
potential springing from discontent with capitalism and/or racism. ${ }^{41}$

The early $20^{\text {th }}$ century witnessed two industrial strikes that morphed into riots. In 1912 a sustained miners' strike in Waihi, widely reported at the time as the 'Waihi Riot', reached a bloody climax when police and nonunion workers attacked a union hall where strikers were taking refuge. ${ }^{42} \mathrm{~A}$ policeman was shot in the stomach, a non-union worker in the knee. The unionist Fred Evans, who is believed to have fired the shots, later died of injuries sustained in a police beating, becoming a martyr for the cause.

A push began in 1913 for a general strike. In late October striking members of the watersiders' union in Wellington were confronted by mounted special constables. A riot ensued. It flared and abated over a period of six days, ${ }^{43}$ prompting Sir Joseph Ward, leader of the opposition, to compare the situation to 'a system of Mexican revolt and civil war'. ${ }^{44}$ The police read the riot act to protestors to prevent them storming parliament buildings and granting police the right to fire on those assembled. ${ }^{45} \mathrm{Naval}$ troops appeared on the streets of Wellington with bayonets fixed to their rifles; machine guns were installed at strategic locations. The unrest in Wellington was quelled only to resurface shortly after in Auckland, where workers heeded the call from the International Workers of the World (IWW) to shut down the city on 8 November. ${ }^{46}$ Having learned hard lessons in Wellington, the police response in Auckland avoided provoking violence. ${ }^{47}$ The ranks of those protesting dwindled, and this sequence of

41 This article aims to give a broad overview of riots in the country. Accordingly, the discussion is restricted, for the most part, to instances of riot that have already been well documented. It should be noted, however, that the existing scholastic record is partial and fragmentary. A comprehensive study of riots in this country remains to be written.

42 See, for instance, 'The Waihi Riot,' Auckland Star, 7 December 1912.

43 Baker, Mutiny, Terrorism, Riots and Murder.

44 As cited in Herbert Roth, Trade Unions in New Zealand: Past and Present (Wellington: Reed, 1973), 38.

45 Mark Derby, personal communication with the author.

46 Shor, 'Bringing the Storm,' 69.

47 Graeme Dunstall, 'Governments, the Police and the Left, 1912-51,' in On the Left: Essays in Socialism in New Zealand, ed. Pat Moloney and Kerry Taylor (Dunedin: Otago University Press, 2002). 
radical labour waned.

The next round of radical unrest in which riots played a part occurred during the Great Depression in 1932. The first was in Dunedin on 9 January, when a procession of the unemployed were refused their demand for relief. They stormed a local grocery store but were unable to breach the line of police already assembled there. ${ }^{48} \mathrm{~A}$ large riot took place in Auckland on 14 April. Postal workers organised a public meeting and demonstration to protest a 10-percent salary cut. Thousands of unemployed workers joined the procession as it made its way up Queen Street. ${ }^{49}$ They were met with a strong show of police force. James Edwards, the leader of the unemployed movement, sought to address the crowd only to be struck down from behind by a blow from a police officer's baton. Edwards recounts what followed:

Now the mob was infuriated. . . I staggered to the balustrade to try and address the crowd. By this time the police had arrived in force and were wielding their batons against the demonstrators and driving them back from the town hall doors, and within seconds the crowd in their thousands had become a frenzied leaderless mob. Whatever I said was drowned in the tumult and uproar and all I could see through the blood that was blinding me, from the wound on my head, was the dark bodies of my fellow men in violent conflict as police and demonstrator encountered one another. ${ }^{50}$

The ensuing riot traversed the length of Queen Street. Naval troops with fixed bayonets quelled the unrest the following day. Then, on 10 May in Wellington protestors assembled to contest hastily passed legislation granting police greater powers for dispersing riots. Shortly thereafter a riot broke out, leaving a trail of broken glass and looted stores stretching along Lambton Quay and up Willis and Manners streets. ${ }^{51}$ In the same period a tramways strike in Christchurch 'resulted in unprecedented scenes of

48 James Edwards, Riot 1932 (Christchurch: Whitcombe and Tombs, 1974).

49 Edwards, Riot 1932, 2.

50 As cited in Edwards, Riot 1932, 2.

51 Baker, Mutiny, Terrorism, Riots and Murder; Edwards, Riot 1932. 
violence and disorder'. ${ }^{52}$

Racism sparked the next round of significant rioting in Aotearoa New Zealand. US servicemen, based north of Wellington during the Second World War, encountered New Zealand soldiers in Wellington city. Tensions had been running high in 1943, in no small part because of the US troops' popularity with local women. A riot was sparked by US soldiers objecting to drinking in the same club as Māori. Over 1,000 soldiers were involved in what became known as 'The Battle of Manners Street'. Smaller skirmishes followed-including a brawl between Māori civilians and US servicemen near the US camp in Otaki. ${ }^{53}$

Prisons have also been sites of riot in Aotearoa New Zealand. There were significant riots at Mt Eden and Paparua prisons in 1965. ${ }^{54}$ The frequency of prison riots increased in the heated international political climate of the 1960s and 1970s, fuelled in no small part by the rise of Black Power in the US. As Newbold writes:

Starting in North America, prisoners, many of them black, began to see themselves as victims of state oppression, a feeling enhanced by the beatings and arrests of political agitators. This awareness was accompanied by a spate of prison riots, many of them organised by state and national prisoners' unions. ${ }^{55}$

These riots escalated in the years 1968-1972. A similar pattern could be seen in New Zealand prisons, where inmates were politicised by events in the US and elsewhere. Riots occurred in Paremoremo, Mt Eden, Mt Crawford, and Paparua over the years 1969-1975. The causes varied:

52 Erik Olssen, 'The New Zealand Labour Movement, 1920-40,' in Common Cause: Essays in Australian and New Zealand Labour History, ed. Eric Fry (Sydney NSW: Allen \& Unwin, 1986), 20.

53 Baker, Mutiny, Terrorism, Riots and Murder.

54 Greg Newbold, The Problem of Prisons: Corrections Reform in New Zealand since 1840 (Wellington: Dunmore Publishing, 2007).

55 Newbold, The Problem of Prisons, 70-71. 
overcrowding, lengthy deprivation, poor treatment. ${ }^{56}$ The following years saw more prison riots-Paremoremo 1998, Spring Hill 2016-but with less frequency. With the prison population in Aotearoa New Zealand disproportionately tilted toward Māori and Pasifika, ${ }^{57}$ it can be argued there is a racialised dimension to these events.

A more specifically racialised 'riot' took place in 1979 with the infamous 'haka party' at the University of Auckland. Engineering students had long undertaken a drunken mock haka at their annual capping celebration. Donning grass skirts, and painting obscenities on their bodies, the engineering students performed a haka laced with racist epithets directed at Māori. Despite requests from Māori students for it to stop, the practice continued. In 1979 a group of Māori and Pasifika students, including members of He Taua (the Māori People's Liberation Movement of Aotearoa), confronted the engineering students as they prepared for their haka party, asking that the grass skirts be removed. A scuffle broke out. Eleven members of He Taua were subsequently arrested and charged with rioting. ${ }^{58}$ This incident does not qualify as a riot in the commonsense notion of this term- a mass of bodies in the streets. What it does underline, however, is the leeway afforded the legal system in being able to designate an event a 'riot', an effective way of denigrating and delegitimising those labelled 'rioter' in the eyes of the public. ${ }^{59}$

The best known example of the state going on riot-footing — again with race a central issue-is its response to protests against the 1981 Springbok tour. History of opposition to New Zealand's sporting contact with the South African rugby team, the Springboks, stretches back to 1921, but the intensity and momentum of these protests increased through the 1960s

56 Newbold, The Problem of Prisons, 71.

57 Gary Raumati Hook, 'The Criminalization of Māori and Pacific Islanders under the Domestic Violence Act 1995,' MAI Review, no. 3 (2009); Robert Webb, 'Māori, Pacific Peoples and the Social Construction of Crime Statistics,' MAI Review, no. 3 (2009).

58 Aroha Harris, Hīkoi: Forty Years of Mãori Protest (Wellington: Huia, 2004).

59 The New Zealand Crimes Act, 1961, section 87, holds that 'A riot is a group of 6 or more persons who, acting together, are using violence against persons or property to the alarm of persons in the neighbourhood of that group'. 
into the 1970s. This cycle of protest reached its climax with 'The Tour' of 1981. ${ }^{60}$ Over an eight-week period 150,000 people attended protests in 28 centres. Protestors stormed test-match pitches and met with violence from rugby fans. Riot police were deployed to quell the protests, intensifying the situation and leading to 'running battles between protestors, the police and rugby fans'. As Harris argues, it appeared 'as if New Zealand was on the brink of civil war' ${ }^{61}$ Again, the protests were not riots in-themselves, but the state response effectively made them so.

A spectacular manifestation of discontent occurred with the Queen Street riot of 1984. The setting was an end-of-school rock concert in Auckland's Aotea Square, attended by approximately 10,000. A power cut interrupted the music and drunken youths on a balcony began urinating on those below. Bottles were thrown in retaliation, police intervened, skirmishes broke out. The concert was ordered to stop, and riot police arrived to direct the crowd down Queen Street. There were further confrontations between the police and members of the crowd. A riot soon followed. ${ }^{62}$ As recounted by one young participant:

People started throwing bottles at the stage and soon there were bottles everywhere, smashing on the concrete of Aotea Square, all around us. It rained bottles. ... Crowds surged down Queen Street, breaking windows and looting shops. Later we caught the bus home and the Police stopped the bus, got on and arrested some people with stolen stuff. The whole day was actually pretty cool, scary but the violence wasn't directed so much at people (at least in my experience) as property. ${ }^{63}$

Many commentators at the time did not look past the spectacular dimension of the riot, seeing only a spontaneous event with no underlying causes: it

60 Trevor Richards, Dancing on Our Bones: New Zealand, South Africa, Rugby and Racism (Wellington: Bridget Williams Books, 1999).

61 Harris, Hikoi, 108.

62 Tony Mitchell, 'On Black Friday: Another Look at the Queen Street Riot,' New Zealand Journal of Media Studies 13, no. 2 (2012), 130-151.

63 As cited in Mitchell, 'On Black Friday,' 130. 
was 'mob hysteria', 'misuse of alcohol', and so on. ${ }^{64}$ Witnesses to the event, however, lay the blame for the escalating situation at the feet of the police. Mitchell, in his analysis of the riot, draws the following conclusion:

Evidence appears that there was a subcultural element involved in the riots, especially gangs, punks and street kids, together with a widespread animosity towards aggressive police tactics. Unemployment seems less of a direct causal issue, although racial tensions were definitely a feature in the arrests and in descriptions of the riots. ${ }^{65}$

We are, here, firmly situated in the terrain of the contemporary riot. Mitchell notes the racialised dimension of the riot, with Māori and Pasifika at the forefront of skirmishes with the police. The presence of street kids was also a factor, a symptom of the wider economic crisis faced by the country.

Ranginui Walker, writing in the aftermath of the riot, and against the backdrop of proleterianisation, poverty, the urbanisation of Māori, and the loss of traditional sources of community, makes the following observation:

If both parents are forced to work there are often no elders at home to meet the children and care for them. They spill out on the cities to become street kids and to search for an identity in gangs. Thus the urban milieu itself spawned the brown proletariat which has generated so much paranoia and occupied considerable media space in the last ten years. Because of their deep sense of alienation these young people do not share in the social and cultural aspirations of middle New Zealand. Add to that their often voiced claim of police harassment and victimisation, and they were a ready-made constituency waiting for a riot to happen, as it did on 7 December $1984 .^{66}$

The Queen Street riot of 1984 indicates the interrelation of race, economic downturn and precarity, surplus population growth, and the advent of the riot. As Clover argues, there are two sources of the contemporary riot:

64 Mitchell, 'On Black Friday.'

65 Mitchell, 'On Black Friday,' 149.

66 Ranginui Walker, Ngā Tau Tohetohe: Years of Anger (Auckland: Penguin, 1987), 154-155. 
excluded and disaffected youth and racialised populations. In the case of the Queen Street riot of 1984 these categories overlapped.

There have also been a number of instances of student riots in Dunedin since the 1990s, with drunkenness routinely cited by media as the cause. In 1990, the Otago Daily Times tells us, a riot took place when '1500 drunken students caused havoc . . . after they upturned cars, lit street fires and pelted police with bottles and bricks' ${ }^{67}$ A different perspective on the event was offered by the Otago University Students' Association, which suggest that the riot 'may well be symptomatic of the increased pressures University life places upon students', including 'a very poor standard of living' ${ }^{68}$ This riot took place against the backdrop of changing tertiary education climate. The Fourth Labour Government imposed a uniform fee on tertiary students in 1989, universities began incrementally raising their fees, and student allowances ceased to be universal from 1991, with student loans introduced. ${ }^{69}$ Student indebtedness and impoverishment increased steadily from this point.

A more explicitly political event took place at Otago University in 1993. A student rally protesting a rise in student fees and related grievances was held outside the registry building to coincide with a meeting of the University Council. Students surrounded the building once the council meeting was underway and police intervened. As recounted by a student participant:

At some point the doors were thrown open and police officers in riot gear jumped over and onto seated students. ... What is very clear is a police officer moving his way down the line of people towards me, pulling

67 '1990: Cars overturned, sofa burnt, as students riot,' Otago Daily Times, 2 February 2012, https://www.odt.co.nz/news/dunedin/1990-cars-overturned-sofaburnt-students-riot

68 Cited in 'A brief history of Dunedin's wildest student riots,' Stuff, 28 April 2019, https://hespinoff.co.nz/society/28-04-2019/a-brief-history-of-dunedins-wildeststudent-riots/

69 Jane Kelsey, The New Zealand Experiment (Auckland: Auckland University Press \& Bridget Williams Books, 1997). 
people out and hitting them if they didn't move. He reached me and yelled something, and pulled at my shirt, ripping it. He then swung his long baton and hit me on the back of the neck. . . . Initially I was stunned, and wandered aimlessly for some seconds. Eventually I went to the aid of a woman in a pink top who was crouched over crying near the large flowerpots. She said that a police officer had kneed her in the back and that she was having trouble breathing. Next thing I knew I was flat on my front. Standing up, I turned around to see a police officer in a white shirt, and I felt a pain in my lower back. ${ }^{70}$

Another student recounts how this rough treatment by the university and police radicalised students, triggering an occupation of the registry in Otago in 1995 and Auckland in $1996 .{ }^{71}$ In the 1993 event police provocation had created a riotous situation, and the subsequent labelling of the event as a 'student riot' worked to undermine public support for victims of police brutality.

Riots became an annual feature of Dunedin student life in the years 2006-2009. These riots often coincided with the 'Undie 500', a rally in which students from Canterbury drove elaborately decorated cars to Dunedin, with numerous stops at bars on the way. The event was cancelled in 2009, following two nights of rioting in the city, which culminated in police 'facing off against a mob of about 600 people'. ${ }^{72}$ Inspector Dave Campbell is quoted as saying that 'The event has once again shown that when large numbers of young adults gather and drink to excess mass disorder is inevitable' - a commonsense view found throughout reportage on the riots. ${ }^{73}$ While significant primary research is needed to draw any sharp conclusions between these riots and students' political-economic context,

70 Kyle Matthews, 'September 28 $8^{\text {th }} 1993$ ' (Hons dissertation, Otago University, 2000), 14 .

71 Cybèle Locke, e-mail message to author, 5 March 2019. This point is also argued by Matthews, 'September $28^{\text {th }} 1993$.'

72 'Undie 500: Rioting in Dunedin for second night,' New Zealand Herald,

13 September 2009, https://www.nzherald.co.nz/nz/news/article.cfm?c_

id=1 \&objectid $=10596992$

73 'Undie 500: Rioting in Dunedin for second night.' 
such events conform with the trends identified in Clover's arguments.

The above history of riots is partial, but it does provide a sense of the place of the riot in this country. It appears the riot is not a common event and has not increased in frequency or intensity in recent history. The most 'notable' riots-in terms of numbers involved and the scale of destruction of private property — fall relatively evenly across the period surveyed. Four broad categories of riot are identifiable: riots with an explicit economic dimension, as when strikes or assemblies of the unemployed became riotous (often through police provocation) and/or when looting was pronounced (examples of which include the Depression-era riots and the Queen Street riot of 1984); protest events that were treated as and/or branded as riots by the state (such as the haka party incident or the Springbok tour protests); riots directly sparked by racism (the least frequent); and riots carried out by disaffected youth (Queen Street 1984 and Dunedin students in 1990 and 2006-2009). That this last type of riot appears to be the most common in the contemporary period suggests some affinities with Clover's periodisation, but the particularities of Aotearoa New Zealand cut against a wholesale adoption of his model for explaining riots here. ${ }^{74}$ Nevertheless, Clover's work provides a useful provocation for thinking through the place of the riot in relation to 'organised' forms of collective action.

The strike is set against the riot in Clover's work, with the latter waxing as the former wanes. Might the history of the strike and organised labour in this country provide some answers as to why the riot is less prevalent here than in other Western states?

\section{The strike and unions}

To understand the history of the strike in Aotearoa New Zealand it is useful to track the changing dynamics of unionism in this country, including the ebb and flow of militant unionism and its correlation with strike waves.

74 Another issue being the different timeframe of the entrenchment of capitalism and its industrial base. 
For the most part the strike was not a prevalent feature here in the $19^{\text {th }}$ century. The first recorded strike was conducted by Māori in the Bay of Islands in 1821 following a wage dispute; the first Pākehā strike was in New Plymouth in $1841 .{ }^{75}$ Most early strikes took place on public works. A common goal was the introduction and defence of the eight-hour working day - a win which, in itself, signalled the relative strength of labour in the country at the time. While slow to take root, unionism grew rapidly. In 1888 there were approximately 3,000 union members in the country; by late 1890 it was claimed that there were $63,000 .{ }^{76}$ As elsewhere, workers in this country were exposed to socialist and communist ideas and were coming to self-consciously identify as members of a class with common interests. ${ }^{77}$ The first true test of this worker militancy was the 1890 maritime strike, a nationwide and trans-Tasman strike. Within Aotearoa New Zealand it involved 8,000 workers across a range of occupations. Middle class opinion turned against the workers, and employers effectively organised to undercut the unions. ${ }^{78}$ The strike was defeated after 77 days.

The labour movement took a parliamentary-political turn in the wake of the strike, forming an alliance with the Liberal Party. An outcome of the alliance, once the Liberals took power, was the introduction of the Industrial Conciliation and Arbitration Act 1894. This act compelled employers to engage in arbitration with employees to settle disputes, with a national Arbitration Court overseeing the process. It was optional for unions as to whether they signed up to the act. Those that did were no longer permitted to strike. The act provided workers with an opportunity to rebuild the movement following the defeat of the maritime strike. For employers 'it offered the alluring prospect of a land free of strikes'. ${ }^{79}$

75 Roth and Hammond, Toil and Trouble.

76 Roth, Trade Unions in New Zealand. Although, Roth notes, this figure is likely exaggerated.

77 Erik Olssen and Clyde Griffen, An Accidental Utopia? Social Mobility \& the Foundations of an Egalitarian Society, 1880-1940 (Dunedin: Otago University Press, 2011); Roth, Trade Unions in New Zealand.

78 Roth, Trade Unions in New Zealand, 15.

79 Olssen, 'The New Zealand Labour Movement, 1880-1920.' 
Labour discontent with the Liberal Government grew in the early $20^{\text {th }}$ century. In 1906 Auckland tram workers undertook the first strike action by a registered union in defiance of the Arbitration Court. The strike was successful and emboldened other unions. ${ }^{80} \mathrm{~A}$ radical period of working class organisation followed.

On the back of a successful miners' strike in Blackball in early 1908, the New Zealand Federation of Labour-commonly known as the 'Red Feds'-formed to challenge the arbitration system. The Red Feds were militant, affirming the primacy of class struggle. Composed from an affiliation of miners', watersiders', shearers', labourers', and other unions for workers in 'unskilled' sectors, the Red Feds represented a different body of workers than the more conservative craft unions. By 1912 its ranks contained a quarter of the country's organised workers. ${ }^{81}$ In the same period the Social Democratic Party (a forerunner of the Labour Party) formed on the platform of an independent socialist politics. The IWW gained traction at this point too-advocating for a radical, syndicalist, and direct-action approach to class conflict. ${ }^{82}$ The Red Feds' publication, the Maoriland Worker, carried material from IWW agitators and other radical writers. With a circulation of 8,500 at this time, it contributed to a vibrant debate in far-left tactics and thought. An economic downturn in 1909 saw declining living standards and rising unemployment, further fuelling radicalism. The militant turn taken by labour found expression in the events of Waihi in 1912, culminating in a general strike in 1913 organised by the Red Feds. The forceful crushing of the general strike broke the power of the Red Feds, and militant unionism was once again derailed across the country.

After quelling the 1913 strike the conservative prime minister William Massey implemented a raft of anti-union legislation, forcing organised labour away from industrial action and back down the path of parliamentary

80 Roth, Trade Unions in New Zealand.

81 Roth, Trade Unions in New Zealand.

82 Shor, 'Bringing the Storm.' 
politics. ${ }^{83}$ The Labour Party formed in 1916. By 1920 most unions had aligned with the party. In 1936 leading unionists, together with the Labour Party, organised the National Industrial Conference; an outcome of which was the formation of the Federation of Labour (FoL) from an affiliation of unions. ${ }^{84}$ By the 1940s, suggests Olssen, the majority of the country's workers thought 'the revolution was complete' - with high wages, job security, free education, comprehensive free healthcare, and generous pensions and superannuation. ${ }^{85}$ The country's 'practical socialism'-a Keynesian state under the government of the Labour Party-was a product of the compromise between organised labour and capital.

By the late 1940s, however, there was a growing restlessness within the labour movement. Radical elements contested the tight compact between the FoL and the Labour Party. ${ }^{86}$ Militant socialist unions and the Waterside Workers' Union (WWU) broke with the FoL in early 1949, forming the rival Trade Unions Congress (TUC). The TUC advocated for industrial action rather than arbitration. The industrial unrest building under the First Labour Government (1935-1949) intensified once the First National Government took power in 1949 under the leadership of Sidney Holland.

This discontent found dramatic expression in the 1951 waterfront dispute. The action involved 22,000 workers at its height. Initially a conflict concerning overtime and wages, Holland treated it as a direct challenge to law and order, ${ }^{87}$ and the mainstream press reported it as a Soviet-led 'communist' takeover of the waterfront. ${ }^{88}$ Public support for the action was low, as was that of the wider union movement (reflecting the dynamics of the TUC's split from the FoL). Any support offered locked-

83 Christopher Wilkes, 'The State as an Historical Subject: A Periodisation of State Formation in New Zealand,' in State and Economy in New Zealand, ed. Brian Roper and Chris Rudd (Auckland: Oxford University Press, 1993), 192-209.

84 Roth, Trade Unions in New Zealand.

85 Olssen, 'The New Zealand Labour Movement, 1920-40,' 24.

86 Olssen, 'The New Zealand Labour Movement, 1920-40.'

87 Wilkes, 'The State as an Historical Subject.'

88 Michael Bassett, Confrontation '51: The 1951 Waterfront Dispute (Wellington: Reed, 1972). 
out workers and those striking in solidarity was deemed illegal—including providing food to the strikers' children. The lockout held for five months but met with increasingly repressive practices from the state. Police violence was common, and the military was eventually deployed to break the pickets on the wharves. ${ }^{89}$ The defeat of the Waterside Workers' Union was simultaneously the defeat of militant unionism in the country at this time. The labour movement entered a 15 -year period of quiescence. ${ }^{90}$

When the Second National Government came to power in 1960, Keith Holyoake, the new prime minister, spoke of how fortunate it was to have the FoL continuing to stand by the government's side - as it had during the unrest of $1951 .{ }^{91}$ The arbitration system so faithfully upheld by the FoL began to face challenges in the 1960s. This reflected wider economic developments and changes within the arbitration system itself: 'Labour scarcity, changing patterns of industrialisation, new workplace technologies, and managerial preference for negotiating their own agreements all contributed to the development of a network of direct bargaining outside the arbitration system..$^{92}$ Better awards were secured outside of the arbitration system than within, emboldening unions in direct bargaining.

The year 1968 witnessed a turning point for industrial relations. The Arbitration Court, tasked with ensuring economic stability, refused to award a general wage order, further undermining the union movement's faith in arbitration..$^{93}$ Workers now pitched their organisational capacity

89 Dick Scott, 151 Days: Official History of the Great Waterfront Lockout and Supporting Strikes, February 15-July 15, 1951 (Auckland: New Zealand Waterside Workers' Union, 1951).

90 Tom Bramble and Sarah Heal, 'Trade Unions,' in The Political Economy of New Zealand, ed. Chris Rudd and Brian Roper (Auckland: Oxford University Press, 1997), 119-140.

91 Roth, Trade Unions in New Zealand.

92 Pat Walsh, 'From Arbitration to Bargaining: Changing State Strategies in Industrial Relations,' in The Political Economy of New Zealand, ed. Chris Rudd and Brian Roper (Auckland: Oxford University Press, 1997), 183-201.

93 Walsh, 'From Arbitration to Bargaining.' 
against employers. Strike rates rose dramatically. By way of comparison, 1966 witnessed 147 strike actions involving 33,132 workers; 1976 had 543 with 263,855 involved; 1977 had the greatest number of strikes recorded in the country to date, at 564; and 1979 witnessed the highest number of workers involved in actions, at 471,450 - 46.2 percent of the country's labour force at the time. ${ }^{94}$ The FoL changed tactics in this period, adopting a more militant 'grassroots' approach to organising. ${ }^{95}$ It spearheaded a national campaign of stopwork meetings in response to the government's wage freeze in 1976. In 1979 it coordinated a national one-day general strike after Muldoon overturned an 11-percent wage increase agreement between drivers and their employers. ${ }^{96}$ The 1979 General Strike is the largest to have taken place in the country. It was the first time blue- and white-collar unions acted together at a national level. ${ }^{97}$

\section{Neoliberalism and union decline}

The increasingly militant working class attracted a 'ruling-class counteroffensive' in the 1980s, ${ }^{98}$ the cruel irony being that the vehicle for this offensive was the Fourth Labour Government elected in 1984. Labour initiated a rapid series of market-driven reforms that had not been foreshadowed in their pre-election manifesto, taking the party's supporters by surprise. A rift opened between the party and union leadership, bringing about 'a deterioration in the relationship between the political

94 Toby Boraman, 'Merging Politics with Economics: Non-Industrial and Political Work Stoppage Statistics in New Zealand During the Long 1970s,' New Zealand Journal of Employment Relations 41, no. 1 (2016): 64-82.

95 Cybèle Locke, Workers in the Margins: Union Radicals in Post-War New Zealand (Wellington: Bridget Williams Books, 2012).

96 Raymond Markey, 'Troubled Times: 1967-88,' in Unions in Common Cause:

The New Zealand Federation of Labour 1937-88, ed. Peter Franks and Melanie Nolan

(Wellington: Steele Roberts Aotearoa, 2011), 145-181.

97 Boraman, 'Merging Politics with Economics.'

98 Bramble and Heal, 'Trade Unions.' 
and industrial wings of the labour movement'. ${ }^{99}$ As Jesson argues, 'The union movement was in an invidious position in the mid-1980s. It found itself being undermined by a Labour Government that it had spent a lot of time and money helping elect, and not in a strong enough position to do anything about it'. ${ }^{100}$

Labour abolished compulsory arbitration in 1987. This move, along with other changes, aimed for a more 'efficient' union sector. ${ }^{101}$ While militant unions had previously opposed compulsory arbitration, because of the shifting balance of power within the economy, this change in industrial policy was now more suited to the interests of employers than workers. In this changing environment the Combined State Unions (CSU) and the FoL jointly pursued a corporatist approach on two fronts: building support within Labour Party conferences to oppose neoliberal reforms; and negotiating in the 'tripartite talks' between unions, employers, and the government in which non-binding wage guidelines were set. ${ }^{102}$ The FoL and CSU combined to form the Council of Trade Unions (CTU) in 1987 in a bid to consolidate the union movement's depleted resources. The CTU continued to pursue the conciliatory path of corporatist negotiation.

On the employer's side, the 'Nissan Way' was promoted in the late 1980 s as a system of workplace reform. It encouraged cooperation rather than confrontation. 'Partnerships' between workers and management were sought at the company level, with workers tasked with increasing efficiency in a bid to save their workplaces. Employers, predictably, saw no positive role for unions in this partnership. ${ }^{103}$ Employees in such workplaces were now caught in the 'affirmation trap' discussed above.

99 Jonathan Boston, 'Wages Policy and Industrial Relations Reform,' in The Fourth Labour Government: Radical Politics in New Zealand, ed. Jonathan Boston and Martin Holland (Auckland: Oxford University Press, 1987), 184.

100 Bruce Jesson, Fragments of Labour: The Story Behind the Labour Government (Auckland: Penguin, 1989), 91.

101 Walsh, 'From Arbitration to Bargaining,' 193.

102 Locke, Workers in the Margins.

103 David Neilson, A Trade Union Perspective of New Zealand's Political Economy (Auckland: W.I.S.E, 1993). 
Rather than accept the CTU's corporatist approach, militant working class unions opted to form the Trade Union Federation (TUF) in 1993. TUF encouraged struggle-based unionism and tried to move the CTU away from tripartism and workplace reform, arguing for an approach that would redistribute resources to low-income and unemployed people. ${ }^{104}$

While Labour's measures were employer-friendly, employers felt they did not go far enough. The decisive step in favour of employers was undertaken by the Fourth National Government (1990-1999) with the Employment Contracts Act 1991 (ECA). Union membership had dropped significantly during the two terms of the Fourth Labour Government, from 63 percent of all waged and salaried workers in 1987, to 54 percent in $1990 .{ }^{105}$ The ECA accelerated this decline. It abolished national award coverage and compulsory unionism, and individual employment contracts replaced collective ones. Unions lost their special privileges, including their tax-exempt status. They were no longer guaranteed access to worksites and the capacity to strike legally was significantly limited. ${ }^{106}$ When strikes did take place in this period they were often met with police violence. For instance, the 1993 Astley's Tannery strike in New Lynn, a predominantly Tongan workplace, was met by police wielding long batons. ${ }^{107}$

By December 1995 union membership had fallen to 21.7 percent of the labour force. ${ }^{108}$ Membership rates have hovered around this rate since, although 2017 saw the figure drop to 17.7 percent. ${ }^{109}$ Strike rates have witnessed a similar fall, dropping from the highpoint of 1977 noted above. To continue giving a snapshot in ten-year blocks: 1987 witnessed 193

\footnotetext{
104 Locke, Workers in the Margins.

105 Kelsey, The New Zealand Experiment.

106 Kelsey, The New Zealand Experiment.

107 Cybèle Locke, e-mail message to author.

108 Walsh, 'From Arbitration to Bargaining.'

109 Union Membership Return Report 2016 (Wellington: New Zealand Companies
} Office, 2016). 
strike actions, involving 80,100 workers; ${ }^{110} 1997$ had 42, involving 7,646 workers; and 2017 had six, involving 421 workers. ${ }^{111}$ The influence of trade unions on state policy has waned, with business interests taking centre stage. ${ }^{112}$ A dramatic upturn in strikes occurred in 2018, with upwards of 70,000 walking off the job, including workers in health, education, service industries, transport, and industrial production. ${ }^{113}$ It is too early to tell if this is a temporary blip or a turning point for organised labour.

\section{Contemporary approaches to unionism}

Broadly speaking, two organisational approaches to unionism have been pursued in Aotearoa New Zealand in the wake of the ECA: the 'partnership model' and 'social movement unionism'. Pioneered by the Public Service Association (PSA) in 1998, the partnership model continues in the vein of the CTU's corporatist approach. The first major partnership deal between a union, employers, and government was signed in 2000. As summarised by Brookes:

Partnership is an elastic concept. When presented to union delegates and activists, it is portrayed as a strategy for stronger worker participation and

110 John Deeks and Peter Boxhall, Labour Relations in New Zealand (Auckland: Longman Paul, 1989). Boraman argues that, numerically, the most significant movement in Aotearoa New Zealand in the 1980s-1990s was composed of the strikes, wild-cat strikes, protests, and related actions that opposed the ECA, involving close to half-a-million participants: Boraman, 'The Myth of Passivity: Class Struggles against Neoliberalism in Aotearoa in the 1990s,' Red \& Green 5 (2005): 25-48.

111 Respectively, 'Work Stoppages: September 2004 Quarter,' (Wellington: Department of Labour, 2004); 'Work Stoppage Information for 2017,' Employment New Zealand, https://www.employment.govt.nz/starting-employment/unions-andbargaining/work-stoppages/

112 Helen Delaney and Nigel Haworth, 'Battling in a Bleak Environment: The New Zealand Context for Partnership,' in Developing Positive Employment Relations: International Experiences of Labour Management Partnership, ed. Stewart Johnstone and Adrian Wilkinson (London: Palgrave Macmillan, 2016), 181-205.

113 'Overworked and underpaid: The revival of strikes in New Zealand,' The Conversation, https://theconversation.com/overworked-and-underpaid-the-revival-ofstrikes-in-new-zealand-111728 
decision making. . . . For other audiences, however, what is stressed is union willingness to cooperate in boosting business profitability. ${ }^{114}$

The Fifth Labour Government was supportive of this approach. It introduced the Employment Relations Act (ERA) in 2000-a piece of legislation that the CTU were formative in developing - seeking to create better conditions for unions than those set by the ECA. ${ }^{15}$ It has been argued that 'The minister responsible for the introduction of the ERA was convinced that a pluralist, voluntarist alternative based on good faith was a forward-looking option for a modern, diversifying economy'. ${ }^{116}$ Critics hold that the ERA only introduced superficial changes to industrial relations and did little to benefit workers. ${ }^{117}$ The Fifth Labour Government and the CTU were committed to working closely with employers to increase productivity. As one enthusiastic business commentator noted: 'The challenge to the CTU and the [Labour] Government is to stand firm against some of their own who might prefer the sluggish safety of protectionism to the dynamic rewards of competition'. ${ }^{118}$ The partnership model worked, to some extent, for large unions like the PSA and the Engineering, Printing and Manufacturing Union. ${ }^{119}$ It was less favourable for unions operating in the precarious and 'less-skilled' sectors of the economy.

'Social movement unionism' (SMU) is an alternative approach to unionism, involving the following features: a grassroots approach to organisation within the union, with delegates and members playing key

114 Grant Brookes, 'Trade Unions and New Zealand's Economic Crisis,' Links: International Journal of Socialist Renewal, http://links.org.au/node/1111

115 Delaney and Haworth, 'Battling in a Bleak Environment.'

116 Delaney and Haworth, 'Battling in a Bleak Environment,' 192.

117 Ian McAndrew, Alan Geare, and Fiona Edgar, 'The Changing Landscape of Industrial Relations,' in Workplace Relations in New Zealand 1976-2016, ed. Gordon Anderson, Alan Geare, Earling Rasmussen and Margaret Wilson (Wellington: Victoria University Press, 2017).

118 Phil O'Reilly, 'The Productivity Challenge,' Business NZ, 2 February 2005, https:/www.businessnz.org.nz/news-and-media/commentaries/2005/the-productivitychallenge

119 Delaney and Haworth, 'Battling in a Bleak Environment.' 
roles; networking and solidarity with groups outside of the union; and the pursuit of broader social justice aims. ${ }^{120}$ The Wellington Hotel and Hospital Workers' Union pioneered this approach in Aotearoa New Zealand. In the late 1980s it campaigned 'beyond the workplace for social and health changes that would assist working-class communities in the greater Wellington region'. ${ }^{121}$ The Living Wage Campaign provides a contemporary example of this approach. As Newman and Jess suggest, this is a campaign that 'places workers within their communities, that grounds them in citizenship, recognising social and economic influences on their lives from beyond the workplace. The movement aspires to a democratic project that changes society and not just employment arrangements in workplaces'. ${ }^{122}$

Unite Union have been at the cutting edge of this approach. With a youthful membership, many of whom are employed in the fast food industry and other precarious industries, Unite uses novel tactics to attract media attention and pressure employers. One of their early actions in 2005, 'the world's first Starbucks Strike', garnered international attention. Treen, one of Unite's founders and organisers, notes that their work is often as much about workers' dignity as bread-and-butter issues. ${ }^{123}$ Unite has influenced other unions, including FIRST (Finance, Industrial, Retail, Stores, and Transport). FIRST often directs its actions at high-visibility targets such as supermarkets on main thoroughfares. Delegates play key roles in

120 Jane Parker, "Reaching out for Strength Within? "Social Movment Unionism" in a Small Country Setting,' Industrial Relations Journal 42, no. 4 (2011): 392-403; Jane Parker and Ozan Alakavunkular, 'Social Movement Unionism as Union-Civil Alliances-A Democratizing Force? The New Zealand Case,' Relations Industrielles/ Industrial Relations 73, no. 4 (2018): 784-813.

121 Cybèle Locke, 'Building Solidarity at the Flax-Roots: Standing Committees for Women, Maori and Pacific Island Members Inside the Wellington Hotel and Hospital Workers' Union, 1979-1989,' Labour \& Industry: A Journal of the Social and Economic Relations of Work 25, no. 3 (2015): 170-184.

122 Annabel Newman and Carol Jess, 'Renewing New Zealand Unions: The Service and Food Workers' Union \& Living Wage Aotearoa,' Labour, Employment and Work in New Zealand (2015), https://ojs.victoria.ac.nz/LEW/article/view/2223

123 Mike Treen, 'Aotearoa/New Zealand: A History of the Unite Union,' Links: International Journal of Socialist Renewal, http://links.org.au/node/4429 
organising actions. In contrast to the partnership model, FIRST follows a 'militant approach and left-of-centre frame that emphasises struggle, [and] is tentative about developing good relationships with employers'. ${ }^{124}$

SMU is a more militant approach to unionism in Aotearoa New Zealand than the 'partnership' model favoured by conservative unions. The dynamics of these two approaches echo historical divisions in the country's union movement. If SMU were to deepen as a process-becoming more embedded in the communities where precarious workers live-then the tendency toward the riot will likely remain marginal in Aotearoa New Zealand. Considering the ever-decreasing membership of unions in this country, however, the gains secured through SMU appear limited at this point.

Further, the novelty of SMU should not be overstated. As Boraman argues, 'many social movements and broad political currents of the . . 1970s influenced, and were influential within, many trade unions'. ${ }^{125}$ The interface between unions and extra-parliamentary activity in that period includes union support of Māori land-rights struggles, the anti-nuclear movement, and opposition to apartheid. An analysis of union publications in the early 1980s reveals an expansion from class-based claims-making to claims specific to Māori and women. ${ }^{126}$ As Locke notes, the increasing number of Māori union officials in the 1970s prompted change in the movement. This change had a cultural dimension, and it was also evident in the breadth of issues addressed, with many Māori unionists holding that economic justice was only achievable when Māori grievances over land and cultural dispossession were addressed. ${ }^{127}$ The movement became increasingly intersectional in its outlook as the 1970s drew to a close, organising around race, gender, and class. The tragedy is that this shift occurred as unionism lost ground to capital. Overall, it seems that discontent in this period

124 Janis Bailey et al, 'Union Power in Retail: Constrasting Cases in Australia and New Zealand,' New Zealand Journal of Employment Relations 40, no. 1 (2015): 1-18.

125 Boraman, 'Merging Politics with Economics,' 77.

126 Dylan Taylor and Sandra Grey, 'From Class-Struggle to Neoliberal Narratives: Redistributive Movements in Aotearoa/New Zealand,' New Zealand Sociology 29, no. 3 (2014): 69-89.

\section{Locke, Workers in the Margins.}


was able to find expression in existing organisations, one of the reasons, perhaps, why the riot has not become more pronounced in this country.

\section{The unemployed workers movement}

Those who were hit hardest by the economic depression of the 1970s managed to organise relatively effectively in the 1980s. As Locke writes:

When depression hit in the 1970s, certain sections of the workforcewomen, Māori, Pasifika, young, unskilled and semi-skilled workers—bore the brunt of layoffs and reduced hours. It was these marginalised workers, with the assistance of the trade unions worst affected by the depression, who forged their own grassroots centres and unions for unemployed workers; they publicised growing unemployment and attacked the 'dole bludger' [stereotype] promulgated by the National Government. ${ }^{128}$

By 1983 there were 28 unemployed and beneficiary groups in the country. The support and tie-in with the union movement faltered once the Fourth Labour Government came to power. Both the CSU and the FoL 'changed their political strategy to one of nonconfrontation and uncensorious support of the Labour Government' - which included the end of support for an independent unemployed movement. ${ }^{129}$ The national body Te Roopu Rawakore o Aotearoa - in its literal translation, a movement of people who had nothing — was formed in 1985. ${ }^{130}$ The Māori protest movement and feminism were influential for Te Roopu members, 'not only in their efforts to publicise and to resist institutional sexism and racism, but in the way non-hierarchical structures and democratic processes were used to build a grassroots movement that encouraged female and Māori leadership'. ${ }^{131}$

Bringing a strong intersectional approach to organising the unemployed

128 Locke, Workers in the Margins, 77.

129 Locke, 'Blame the System, Not the Victim!' International Labour and WorkingClass History 71 (Spring 2007): 170.

130 Locke, 'Blame the System, Not the Victim!'

131 Locke, Workers in the Margins, 108. 
and beneficiary movement, activists in Aotearoa New Zealand were able to channel diverse currents of discontent into effective resistance-resistance that found expression in the People's Centres opened in various locations around the country, where low-cost health-care and free advocacy services could be accessed by the poor and unemployed. And while the state reduced its welfare provision significantly over this period it still provided a limited safety-net for those hit hardest by the country's economic downturn. The actions of Te Roopu helped slow the rollback of these services and supported those who needed to access them. Arguably, such organisation diffused the impulse to riot found elsewhere.

Recent campaigns from within the union sector, like the Living Wage movement, the push for equal pay, union alliances with iwi to take on employers (as seen with the Iwi Leadership Forum actively supporting the Meatworkers Union in its actions against Talley's in 2012), and the drive from unions like FIRST to organise labour-hire and migrant workers in recent years, can also be seen as countering the tendency to riot.

In taking a broad-view of unionism in this country the following points can be made. While there is a strong tradition of militant unionism in Aotearoa New Zealand, the movement has tended toward conciliatory relations with capital and the state, largely because of the arbitration system and the close ties that developed between the Labour Party and union bodies like the FoL and CTU. Militant unionism, when it appeared, often met with violent repression. From the 1970s unionism in this country became increasingly intersectional in its outlook; however, over this same period it also faced fierce and sustained attacks from the capitalist class. The policies of the Fourth Labour Government and the Fourth National Government hollowed out the union movement. Since the ECA, unions have generally followed either the partnership approach or SMU.

The approach pursued by the unemployed workers and beneficiaries' movement in the 1980s, and SMU more recently, suggests that the organisational path remains more attractive for the economically marginalised than the riot. But despite the recent uptick in strike activity and the work of campaigns like the Living Wage movement, the current 
outlook is bleak. Only one organisation, Auckland Action Against Poverty, occupies the space left by this movement; Te Roopu dissolved in the 1990s; the People's Centres are gone; union membership is at an historic low; and inequality is pronounced. In taking a broad view of the situation in this country, the strike (and union organisation) has been far more prevalent than the riot. However, while the conditions fuelling contemporary riots have not been as marked here as elsewhere, the current situation is such that rioting may yet become a prominent dimension of resistance in this country.

\section{Future riots?}

As argued earlier, some correlations can be found between the situation in this country and those identified by Clover as fuelling contemporary riots in Western societies. The Queen Street Riot of 1984 can be explained, in part, by Clover's theorisation-it was primarily the result of economic depression and racialisation. Yet, overall, it appears the riot does not present the same set of potentialities (if we are to view it this way) here as elsewhere. This is arguably due to different racial dynamics in this country and the organisational approaches deployed by the country's most precarious workers and communities. ${ }^{132}$

It may also be that the occupation takes the place of the riot in this country. For Māori one of the principal objects of struggle has been reclaiming land lost through colonisation. As Harris notes, occupation as a means of drawing attention to grievances around land has been a longstanding tactic for Māori-the 1877 occupation of a sheep station in Ōmārama by Ngāi Tahu is an early example. ${ }^{133}$

As with strikes, there have been waves of occupations. Along with the Hìkoi, this tactic came to the forefront of Māori politics in the 1970s, a prominent example being the occupation of Ōrākei (Bastion Point) by

132 The discussion here is limited to Māori and Pasifika, due to the relatively large amount of material available on these populations. A fuller treatment of racial dynamics in this country falls outside the scope of this article.

133 Harris, Hìkoi. 
Ngāti Whātua and supporters in 1977. It held for 506 days before 600 army and police forcefully evicted it. Māori resistance during the Fourth National Government became particularly intense following revelations that the government sought to impose a one-billion-dollar 'fiscal envelope' on Treaty settlements. Waitangi Day in 1995 witnessed 500 Māori protestors engaging in a 'full scale battle with police'. ${ }^{134}$ Another wave of occupations followed, including the 80-day occupation of Pākaitore by Whanganui iwi. ${ }^{135}$ A contemporary example is the SOUL (Save Our Unique Land) occupation, which seeks to save land confiscated by the Crown in 1863 at Ihumātao from high-priced housing development. ${ }^{136}$ Whether this occupation signals the start of another wave remains to be seen.

Arguably, the logic of the commune grounds such occupations. The occupation enables, albeit temporarily and precariously, a life other than that dictated by capital. It stands opposed to the atomised culture fostered by colonisation. ${ }^{137}$ The communal logic of the occupation harbours emancipatory potential. It is frequently informed by the values of the Marae and is often a reclamation of the site of a previous marae to be refounded through the act of occupation.

Might it be, though, that the riot is already with us as a 'modality of life' for some sections of the 'surplus population' in Aotearoa New Zealand? South Auckland presents a ready example of a location that is host to the dynamics of the contemporary riot: racialisation, relative poverty, status frustration, punitive state actions. It should be noted that in turning to this example I do so as external observer, offering only a partial, fragmentary, and no doubt distorted view. ${ }^{138}$

South Auckland's population haunts the white psyche as a latent

134 Boraman, 'The Myth of Passivity,' 12.

135 Harris, Hìkoi.

136 Tim McCreanor, Frances Hancock, and Nicola Short, 'The Mounting Crisis at Ihumaatao,' Counterfutures 6 (2016): 139-148.

137 Boraman, 'The Myth of Passivity.'

138 To offset my own positionality, I rely on the work of Māori and Pasifika scholars to develop this discussion. 
threat. ${ }^{139}$ Negative stereotypes of this population surface regularly in national media. ${ }^{140}$ As Hook notes, 'There is a perception held by the general public that Māori and Pacific Islanders are responsible for most of the crimes perpetrated on the streets of New Zealand as well as in the homes today'. ${ }^{141}$ South Auckland presents the threat, in the minds of the 'average Kiwi', of a population teetering perpetually on the brink of crime and violence, a prominent recent example being coverage of Pasifika rugby league fans during the 2017 Rugby League World Cup. As Wall reports, 'Many people have voiced concerns about the portrayal of Tongan and Pacific Island supporters in the media, which they feel has exacerbated the police response'. ${ }^{142}$ The police were aggressive. In the wake of the TongaEngland match police snatched flags from Tonga supporters and smashed the poles on the pretext these could be used as weapons. An Ōtahuhu resident describes her reaction to the police response:

It felt like they were in a riot mode. They definitely wanted their presence to be felt in a really assertive way. Their presence was aggressive and [it] didn't feel like they were there to support the energy, which was really disappointing. ${ }^{143}$

These suburbs are sites of racialised poverty, with Māori and Pasifika disproportionately bearing the negative outcomes of the country's changing

139 Alex Latu and Albany Lucas, 'Discretion in the New Zealand Criminal Justice System: The Position of Maori and Pacific Islanders,' Journal of South Pacific Law 12, no. 1 (2008): 84-93

140 Jean Allen and Toni Bruce, 'Constructing the Other: News Media Representations of a Predominantly "Brown" Community in New Zealand,' Pacific Journalism Review 23, no. 1 (2017): 225-244. Tim McCreanor et al, 'The Association of Crime Stories and Māori in Aotearoa New Zealand Print Media,' Sites 11, no. 1 (2014): 121-144.

141 Hook, 'The Criminalization of Māori and Pacific Islanders,' 3.

142 Jamie Wall, "It felt like they were in a riot mode": Police tactics turn ugly in Otāhuhu,' The Spinoff, 26 November 2017, https://thespinoff.co.nz/society/26-11-2017/ it-felt-like-they-were-in-a-riot-mode-police-tactics-turn-ugly-in-otahuhu/

143 Wall, "It Felt Like They Were in a Riot Mode." 
economic fortunes. ${ }^{144}$ Mila suggests that 'Pacific peoples are an almost "textbook" example of an ethnic minority experiencing significant and enduring inequality: indeed, a Pacific person living in New Zealand is 2.6 times more likely than the average person to be living in poverty'. ${ }^{145}$ This weighs heavily on youth:

young [Pacific] people have to contend with the hardest lesson that the labour market has to teach: that the ability to supply labour does not mean that you are in demand. This group has been described as 'the lost generation': bright, eager — and unwanted; and no groups are as unwanted as Pacific and Māori young people. ${ }^{146}$

As economic opportunity recedes, the punitive dimension of the state becomes more pronounced. Work and Income, the government department tasked with administering benefits, presents one face of the punitive state, increasingly oriented as it is towards punishing the poor and blaming them 'for the poverty they have no part in creating'. ${ }^{147} \mathrm{Law}$ and order is another face of the punitive state, and suburbs with high concentrations of Māori and Pasifika are subject to discriminatory police practices and high rates of incarceration. ${ }^{148}$

The negative stereotypes projected onto South Auckland's Māori and

144 Counties Manakau Health, Demographic Profile: 2013 Census, Population of Counties Manukau (Auckland: Counties Manukau Health, 2015).

145 Karlo Mila, 'Only One Deck,' in Inequality: A New Zealand Crisis, ed. Max Rashbrooke (Wellington: Bridget Williams Books, 2013), 91.

146 Mila, 'Only One Deck,' 99. See also: Damon Salesa, Island Time: New Zealand's Pacific Futures (Wellington: Bridget Williams Books, 2018).

147 Auckland Action Against Poverty, 'Not Enough Left: Beneficiaries speak on their visions for welfare, work and housing,' Auckland Action Against Poverty, https:// d3n8a8pro7vhmx.cloudfront.net/aaap/pages/28/attachments/original/1505687996/ Not_Enough_Left_demand_document.pdf?1505687996

148 Webb, 'Māori, Pacific Peoples and the Social Construction of Crime Statistics'; Latu and Lucas, 'Discretion in the New Zealand Criminal Justice System'; Kim Workman and Tracey McIntosh, 'Māori and Prison,' in The Palgrave Handbook of Australian and New Zealand Criminology, Crime and Justice, ed. Antje Deckert and Rick Sarre (Basingstoke: Palgrave Macmillan, 2017), 725-735. 
Pasifika residents, alongside discriminatory policing and disproportionately high rates of economic inequality, presents a set of features that map onto Clover's discussion of the contemporary riot as a 'modality of life'. As elsewhere there is a chance this could take spectacular form again-Queen Street riot 2.0. That this tendency is not apparent at this point, however, signals that existing forms of community-belonging and organisation are effective for these populations despite adverse external conditions. ${ }^{149}$

A final consideration might be the geography of Auckland as a city. Bradford offers the following observations from a 'Left activist perspective' in the 1980s and 1990s:

We didn't see riots or angry demonstrations erupting in the south of Auckland. The 'enemy' of unemployed and low paid workers, the hyperrich, were seen to be located in the CBD headquarters of banks and big companies, the stock exchange, Queen St, and the rich suburbs close to town (e.g. Parnell, Remuera, Herne Bay-Ponsonby and Grey Lynn can be added to this now). People tended to come into Queen St for rallies, demos and the music events that in one case led to the Queen St riot in 84. ... I guess the main times vibrant action has occurred away from the city was during anti-apartheid and other specific campaigns where key targets were elsewhere. In other words, South Auckland lacked targets for rage, comparatively speaking. ${ }^{150}$

Further, Aotearoa New Zealand does not have the same degree of urban housing intensification of racialised and relatively-disadvantaged populations as seen in other countries. It may be that Aotearoa New Zealand is too suburbanised to encourage rioting.

149 Further, Salesa argues that Pasifika - including those in South Aucklandcontinue to effectively influence unions and Labour Party policy: Salesa, Island Time: New Zealand's Pacific Futures.

150 Sue Bradford, e-mail message to author, 12 March 2019. 


\section{Conclusion}

The radical Left in Aotearoa New Zealand is confronted with the challenge of envisioning how to effectively realise substantive positive change. Class, party, and union no longer provide positions of organisational strength, which is not to say that they cannot do so once again. ${ }^{151}$ Inequality is pronounced, precariousness widespread, and increasingly large proportions of the population are deemed surplus to requirements by capital—an exclusionary process with a racialised dimension. It is within such a context that some Left theorists have identified the riot as an increasingly prevalent form of resistance.

While patterns of labour militancy and decline in Aotearoa New Zealand are broadly consistent with other Western countries-excepting the mid- $19^{\text {th }}$ century when the colony was in its infancy-the dynamics of the riot differ. While there is some cross-over with the period of contemporary riots presented by Clover, it would appear that organisations on the Left were able to somewhat constructively address issues of race and class together-as was notably the case with Te Roopu Rawakore o Aotearoa. However, this did not happen in the context of a strong Left, with the Left on the back-foot after the Labour Party's neoliberal reforms.

That the riot has not become more pronounced in the neoliberal period-despite increasing levels of inequality and the hollowing out of unions - suggests that existing forms of organisation are adequate for the time being. For instance, traditional forms of Māori resistance, such as occupation, continue to prove durable and effective. This accounts, in part, for why the racialised dimension commonly identified with the contemporary riot has not been more pronounced here. However, to the external observer at least, Clover's expanded view of the riot as a 'modality of life' appears to have some saliency when considering the interplay of race and ethnicity, discriminatory policing practices, and pronounced and

151 I have argued elsewhere as to the continued relevance of the party for organisation on the Left: Dylan Taylor, 'Movements, Party, State,' in New Forms of Political Organisation, ed. Campbell Jones and Shannon Walsh (Auckland: Economic and Social Research Aotearoa, 2018), 58-67. 
enduring economic inequality in areas like South Auckland. That the riot has not increased in frequency and intensity in such areas may be due to the suburban nature of Aotearoa New Zealand's cities, or because of the effective networks of community organisation and support. Further research is required if firm conclusions are to be drawn here.

While the riot is not a pronounced feature of the social landscape in Aotearoa New Zealand, identifying riots as potential sites of political possibility and understanding the wider structural dynamics in which they emerge is a productive exercise. It goes beyond the shallow denunciations of riots that commonly appear in the popular press. Such denunciations tend to harbour racial and class prejudices. The riot is political and deserves to be understood as such. That said, to await the riot, in the hope it will open onto an emancipatory political sequence, is a futile position for the Left to assume. Considerations of the riot provide one means of mapping the unclear terrain of class, capital, and contestation today. But such mapping is only useful if it is accompanied by organisation on the terrain revealed. 